\title{
Perceived Parental Acceptance: Rejection and Conflict Styles of Adults
}

\author{
J. Parameswari \\ Assistant Professor, Periyar University, Salem, Tamil Nadu, India \\ E-Mail: paramj25@gmail.com
}

\begin{abstract}
Parents greatly affect their children's behaviour. Children model everything parents do and incorporate what they see into their own lives. Parenting skills and behaviour play a vital role in development of children's positive attitude and social behaviour that are essential for healthy living. The way we handles conflict is also significant for a quality living. The present study examined the relationship between perceived parental acceptance-rejection, and conflict styles of adults. For the purpose of the study, a Sample of 250 college teachers (134- male teachers and 116- female teachers) from colleges in and around Dharmapuri were selected systematically. The study adopted survey research design. The Adult Parental Acceptance-Rejection Questionnaire (short form) (Rohner, 1984), and Organizational Conflict Inventory (Rahim, 1983) were used to collect the data. The result revealed significant relationship between perceived parental acceptance-rejection and conflict styles of adults. Males reported significantly more use of competing style of conflict than females. Further, no significant difference was noticed between students from rural and urban in perceived parental acceptance-rejection, and conflict styles. Also, there is no significant difference in perceived parental acceptancerejection, and conflict styles based on birth order and marital status.
\end{abstract}

Keywords: Parental Acceptance and Rejection, Conflict Style, Adult, Parent Nurturance, Family

\section{INTRODUCTION}

Family is considered to be the source of socialization because a child's first and foremost school is their family. Bayard and Fiebert (1977) stated that parenting is associated with social competence, social responsibility, as well as to intellectual assertiveness, and creativity of the child. It is important to notice that parental attitudes toward their child have a long-term impact on the child's adaptive and maladaptive functioning in life (LeVine, Miller, \& West, 1988; Whiting \& Edwards, 1988). Parental acceptance and rejection have major consequences in behavioural, cognitive and emotional development of children and also for the personality functioning of adults (Rohner, 1985). Some children and adults have the resilience to cope more effectively than children and adults who experiences childhood rejection. (Rohner, 2004). Rohner's (2002) metaanalysis research revealed that the child who experienced the parental rejection tends to experience the pain of rejection in their adulthood and children who suffered parental rejection tend to develop difficulties forming trusting relationships in adulthood. Technical advancement has changed the structure of entire society. This made different group of people to live together for the purpose of work. Having conflict management skills is important for every individual in today's competitive world (Rasmusson, 1999; Farrell, 1998; Hemsath, 1997).

Perceived parental rejection predicted increase in behaviour problems and decrease in prosocial behaviour of children (Putnick, et.al 2015). Parental warmth and affection may possibly lower the extent to which children appraise conflict as threatening to the self or family structure (Davidov \& Grusec, 2006; Maccoby \& Martin, 1983). Children who experienced greater parental warmth are more likely to positively view the interpersonal relationship which in turn helps to prevent the development of maladaptive outcomes. Cann. et al., 2007 stated that Individuals who received parental warmth and affection use collaborating, compromising and accommodating styles of conflict where they show concern for others and self. On the other hand, individuals who use avoiding and competing styles of humour are the one who experienced lesser parental warmth. Children who received parental warm from both parents were associated with less conflict, more problem solving and less withdrawal (Cann.et al., 2007). Shih and Susanto (2010) stated that emotional intelligence was an antecedent of conflict management styles for collaborating and compromising styles. Brewer, Mitchell, and Nathan (2002) stated that males were highest on the competing conflict styles whereas females were highest on the avoiding styles. Individuals with upper organizational status used collaborating styles and lower status individuals used avoiding and accommodating styles (Brewer, Mitchell, and Nathan, 2002).

This paper explores how perceived parental acceptance and rejection is associated with conflict handling styles of adults. Quality of parenting is important to promote child well-being. Quality of parenting not only involves physical elements but also non-physical elements. Knowledge on quality parenting has not always been adequate to give all parents the information and support they need. This study has taken a step to provide information on the lacking knowledge.

\section{METHODS}

\section{A. Objectives}

1. To explore the relationship between parental acceptance-rejection, and conflict styles

2. To study gender difference in conflict style of adults. 
3. To study the difference in conflict styles based on marital status, order of birth and locality.

\section{B. Hypotheses}

1. There will be a significant difference in conflict styles of adults on the basis of gender

2. There will be a significant difference in conflict styles of adults on the basis of their marital status.

3. There will be a significant difference in conflict styles of adults on the basis of their locality.

4. There will be a significant difference in conflict styles of adults on the basis of their order of birth.

5. There is a significant relationship between parental acceptance- rejection and conflict styles.

\section{Instruments}

1. Organizational Conflict Inventory (Rahim, 1983) was used to know the conflict styles. The Internal Cronbach's alpha of the scale is 0.72 to 0.76 .

2. The Adult Parental Acceptance-Rejection Questionnaire (short form) (Rohner, 1984) was used to assess parental warmth. The Cronbach alpha of the scale is 0.70 .

\section{Sample}

The population for this study consists of college teachers (aged between 24 \& 40 years) from colleges in and around Dharmapuri. There are 18 arts and science colleges having 717 teachers. Sample of 250 college teachers (134-male teachers and 116-female teachers) were selected using systematic sampling method.

\section{RESULTS AND DISCUSSION}

From the table $\mathrm{I}$ it is noticed that the $\mathrm{Z}$ values are not significant for gender. It is concluded that male and female do not differ significantly in conflict styles. Hence the hypothesis is not accepted. It is equally important to point out that the males have shown significantly higher competing handling style of conflict. Men are taught to characterize themselves in terms of control and dominating and are socialized to be more independent, assertive, and aggressive (Eagly and Karau, 1991). The reason for men being more competing is most probably their innate higher concern to raise their power, and status, because masculinity is directly linked to competition and winning which is the consequence of their historical role of being more dominant. In handling conflict men are more competitive (Rubin and Brown, 1975) and aggressive (Kilman and Thomas, 1977).

TABle I CONFlict STYles OF Adults BASEd ON Gender

\begin{tabular}{|l|c|c|c|c|}
\hline \multirow{2}{*}{\multicolumn{1}{|c|}{ Variables }} & \multicolumn{2}{|c|}{ Mean Rank } & \multirow{2}{*}{ Z value } & \multirow{2}{*}{ P value } \\
\cline { 2 - 5 } & Male (134) & Female (116) & & \\
\hline Conflict collaborating & 120.18 & 131.65 & 1.254 & $0.21^{\text {NS }}$ \\
\hline Conflict accommodating & 118.28 & 133.84 & 1.702 & $0.089^{\text {NS }}$ \\
\hline Conflict competing & 136.88 & 112.35 & 2.682 & $0.007^{*}$ \\
\hline Conflict avoiding & 128.84 & 121.64 & 0.788 & $0.431^{\text {NS }}$ \\
\hline Conflict compromising & 127.18 & 123.56 & 0.396 & $0.692^{\text {NS }}$ \\
\hline
\end{tabular}

Parents usually buy dolls for girls and toy guns for boys. Parents willingly encourage the aggressive behaviour of boys, and not of girls. Directly and indirectly, people learn that men are aggressive, and women not to be aggressive (Berkowitz, 1993). This may be the reason for men having higher competing handling conflict style.

TABle II CONFliCt StYles Of Adults BASED ON MARITAl STATUS

\begin{tabular}{|c|c|c|c|c|}
\hline \multirow{2}{*}{ Variables } & \multicolumn{2}{|c|}{ Mean Rank } & \multirow{2}{*}{$\mathbf{Z}$ value } & \multirow{2}{*}{ P value } \\
\hline & Unmarried (127) & Married (123) & & \\
\hline Conflict collaborating & 133.85 & 116.87 & -1.86 & $0.063^{\mathrm{NS}}$ \\
\hline Conflict accommodating & 132.11 & 118.67 & -1.473 & $0.141^{\mathrm{NS}}$ \\
\hline Conflict competing & 122.29 & 128.81 & -0.715 & $0.475^{\mathrm{NS}}$ \\
\hline Conflict avoiding & 125.11 & 125.90 & -0.086 & $0.932^{\mathrm{NS}}$ \\
\hline Conflict compromising & 129.73 & 121.13 & -0.944 & $0.345^{\mathrm{NS}}$ \\
\hline
\end{tabular}

From the table II it is found that the $\mathrm{Z}$ values are not significant for all the dimensions of conflict styles. Hence the hypothesis is not accepted. The result in the present study contradicts the study by Vokic and Sontor (2009) which states that married people use higher accommodating conflict handling style than unmarried. In the group of 
adults chosen for the study there is no significant difference in their conflict styles based on their marital status. This shows that the chosen adults have not changed their way of handling different situations after their marriage. Generally it is difficult to suddenly change the way people react to situations. Hence this could be the reason that adults do not differ in use of conflict styles on the basis of their marital status.

TABle III CONFLiCt Styles OF Adults Based ON LOCALity

\begin{tabular}{|c|c|c|c|c|}
\hline \multirow{2}{*}{ Variables } & \multicolumn{2}{|c|}{ Mean Rank } & \multirow{2}{*}{$Z$ value } & \multirow{2}{*}{$P$ value } \\
\hline & Rural (162) & Urban (88) & & \\
\hline Conflict collaborating & 123.03 & 130.05 & -0.735 & $0.462^{\mathrm{NS}}$ \\
\hline Conflict accommodating & 125.05 & 126.33 & -0.134 & $0.893^{\mathrm{NS}}$ \\
\hline Conflict competing & 120.75 & 134.25 & -1.414 & $0.157^{\mathrm{NS}}$ \\
\hline Conflict avoiding & 120.87 & 134.02 & -1.376 & $0.169^{\mathrm{NS}}$ \\
\hline Conflict compromising & 123.75 & 128.72 & -0.521 & $0.603^{\mathrm{NS}}$ \\
\hline
\end{tabular}

From table III, it is found that the $\mathrm{Z}$ values are not significant for the dimensions of conflict handling styles. Hence the hypothesis is not accepted. It is concluded that adults from rural and urban area do not differ significantly in their conflict handling styles. Humans are emotional beings, irrespective of their locality people are similar in terms of human interaction. In the development of emotional intelligence cultural-values play an important role
(Miller et. al, 1997). Though livelihood of people are different based on their locality they share similar culturalvalues from society. Based on their interaction and cooperation one can develop conflict handling styles from society despite of locality (rural or urban). Probably this could be the reason that adults from rural and urban area do not differ significantly in their conflict handling styles.

TABLE IV CONFLict STYles Of AdULTS BASEd ON ORdER OF BIRTH

\begin{tabular}{|l|c|c|c|c|c|}
\hline \multirow{2}{*}{\multicolumn{1}{|c|}{ Variables }} & \multicolumn{3}{c|}{ Mean Rank } & \multirow{2}{*}{ Chi-square value } & \multirow{2}{*}{ P value } \\
\cline { 2 - 6 } & First (95) & Middle (86) & Last (69) & & \\
\hline Conflict collaborating & 116.01 & 129.33 & 133.80 & 2.798 & $0.247^{\mathrm{NS}}$ \\
\hline Conflict accommodating & 122.11 & 122.73 & 133.62 & 1.213 & $0.545^{\mathrm{NS}}$ \\
\hline Conflict competing & 124.48 & 122.12 & 131.11 & 0.625 & $0.732^{\mathrm{NS}}$ \\
\hline Conflict avoiding & 129.98 & 119.01 & 127.42 & 1.111 & $0.574^{\mathrm{NS}}$ \\
\hline Conflict compromising & 119.00 & 122.18 & 138.59 & 3.239 & $0.198^{\mathrm{NS}}$ \\
\hline
\end{tabular}

The above table shows that there is no significant difference in conflict styles of adults on the basis of their order of birth. It is not the child's number in the order of births which influences his/her character, but the situation into which he/she is born and the way he/she interprets it (Ansbacher \& Ansbacher, 1956).

The role child adopts in his/her interaction with others is referred as psychological position (Shulman and Mosak, 1977). Psychological position of the child is more important than birth-order. Gender also plays a crucial role than birthorder. A third-born child who is the first son in a family can be treated like a first-born child. In this case an elder girl may develop a sense of inferiority.

In today's society gender and psychological position affects some birth-order perceptions, this might be the reason that adults do not differ significantly in their conflict handling styles. It is observed from the table $\mathrm{V}$ that almost all the correlation co-efficient are significant and hence the hypothesis is accepted. It is concluded that the parental acceptance-rejection and conflict styles had significant positive and negative association with each other.

Collaborating style of conflict is positively correlated with the all the dimensions of parental rejection. People with low relational value take steps to build stronger social bonds (Baumeister \& Leary, 1995; Williams, 2001). Rejections lead them to work hard to increase their acceptability to others by behaving in socially desirable ways. This may be the reason for the significant relationship.

Accommodating style of conflict is positively correlated with all dimensions of mothers' rejection and fathers' undifferentiated rejection and also negatively correlated with mother warmth. To respond to perceived rejection the initial step people take is doing favours to others, to show their relational value (Leary, Twenge \& Quinlivan, 2006). 
TABle V Relationship Of Parental AcCePtance-Rejection With Conflict Styles

\begin{tabular}{|l|c|c|c|c|c|}
\hline \multicolumn{1}{|c|}{ Variables } & $\begin{array}{c}\text { Conflict } \\
\text { Collaborating }\end{array}$ & $\begin{array}{c}\text { Conflict } \\
\text { Accommodating }\end{array}$ & $\begin{array}{c}\text { Conflict } \\
\text { Competing }\end{array}$ & $\begin{array}{c}\text { Conflict } \\
\text { Avoiding }\end{array}$ & $\begin{array}{c}\text { Conflict } \\
\text { Compromising }\end{array}$ \\
\hline Mother-warmth & $-0.187^{* *}$ & $-0.171^{* *}$ & $0.271^{* *}$ & -0.017 & $-0.160^{* *}$ \\
\hline Mother-hostility & $0.136^{*}$ & $0.141^{*}$ & $-0.181^{* *}$ & 0.111 & $0.241^{* *}$ \\
\hline Mother indifference & $0.215^{* *}$ & $0.218^{* *}$ & $-0.216^{* *}$ & $0.124^{*}$ & $0.286^{* *}$ \\
\hline $\begin{array}{l}\text { Mother- } \\
\text { undifferentiated } \\
\text { Rejection }\end{array}$ & $0.189^{* *}$ & $0.159^{*}$ & $-0.180^{* *}$ & 0.060 & $0.158^{*}$ \\
\hline Father warmth & 0.003 & -0.015 & 0.110 & 0.037 & -0.036 \\
\hline Father hostility & $0.172^{* *}$ & 0.122 & $-0.193^{* *}$ & 0.010 & $0.128^{*}$ \\
\hline Father- indifference & $0.707^{* *}$ & 0.102 & 0.075 & $-0.157^{*}$ & 0.005 \\
\hline $\begin{array}{l}\text { Father- } \\
\text { undifferentiated } \\
\text { Rejection }\end{array}$ & $0.204^{* *}$ & $0.190^{* *}$ & -0.120 & 0.053 & $0.220^{* *}$ \\
\hline
\end{tabular}

Longsuffering people are likely to be more cooperative and less assertive. By being less assertive they willingly put themselves down to meet the requirements of others. Contradictory to the accommodating style of conflict, competing style has negative relationship with dimensions of mothers' rejection and fathers' hostility and undifferentiated rejection. Disconnection and rejection from the parents may cause the children to feel insecure about the relationship. As adults, these insecurely attached children may be anxious about their relationship with others. To feel safe and secure in their relationship they try to avoid competing with others. There is a positive relationship between mothers' indifference and avoiding conflict style, whereas fathers' indifference is negatively correlated with avoiding style. When mothers fail to be kind and loving towards their children they feel inferior and insecure, these feelings make them less assertive and Uncooperative. Typically, these children as adults when face tough situations try to withdraw and turn their emotions inward. On the other hand, when father is indifferent the child's tendency to use avoiding style decreases. This may be because generally, children are more attached to their mother than father. When mother shows indifference, they feel very low emotionally whereas when father shows indifference, they may feel that they have to show their father what they really are and hence tend to develop the positive behaviour and attitude in them. Compromising style is negatively correlated with mother warmth but positively correlated with dimensions of mothers' rejection and fathers' rejection. It is natural that when mother do all things as the child desires, the child later may not compromise. Also sometimes when parents show rejection the child may be adamant and may change his/her behaviour. These tendencies in children may not have changed even after they have grown.

\section{CONCLUSION}

Difference in competing conflict style based on gender is seen. Collaborating humour style correlated with mother warmth and parent's rejection while accommodating conflict style correlated with mother warmth and rejection and father undifferentiated rejection. Competing is correlated with mother warmth and rejection and father hostility. Avoiding style of conflict is correlated with parent's indifference. Compromising is correlated with mother warmth and rejection and father's hostility and undifferentiated rejection.

\section{IMPLICATION}

Conflict is common, and it's a part of life. It is expected because people do not always get along or agree with others. Because conflict is common in everyone's life, the ability to resolve conflicts effectively is an essential skill for everyone. If handled ineffectively, conflict can turn into personal dislike, and lead to relationship breakdown. Sometimes, conflict leads to bullying, or to abuse and aggressively dominate someone. Conflict resolution plays a large part in prevention of bullying. Conflict resolution requires individuals to assert themselves while respecting others and also requires negotiating in order to solve problems and find solutions. All of these components of conflict resolution can build stronger relationships while also preventing bullying. Children should be encouraged to develop conflict handling skills in order to maintain healthy interpersonal and intrapersonal relationship by providing training at an early age. Children should be encouraged to develop positive ways of handling conflicts in order to maintain healthy interpersonal and intrapersonal relationship by providing training at an early age.

\section{REFERENCES}

[1] Ansbacher, H. L., \& Ansbacher, R. R. (Eds.). (1956). The Individual Psychology of Alfred Adler. New York: Basic Books.

[2] Baumeister, R. F., \& Leary, M. R. (1995). The need to belong: Desire for interpersonal attachments as a fundamental human motivation. Psychological Bulletin, 117(1), 497-529.

[3] Bayard-de-Volo, C. L., \& Fiebert, M. S. (1977). Creativity in the preschool child and its relationship to parental authoritarianism. Perceptual and Motor Skills, 45(1), 170.

[4] Berkowitz, L. (1993). Aggression: Its causes, consequences, and control. New York: Academic Press.

[5] Brewer, N., Mitchell, P., \& Weber, N. (2002). Gender role, organizational status, and conflict management styles. International Journal of Conflict Management, 13(1), 78-94. 
[6] Cann, A., Norman, M. A., Welbourne, J. L., \& Calhoun, L. G. (2007). Attachment styles, conflict styles and humour styles: Interrelationships and associations with relationship satisfaction. European Journal of Personality, 22(2), 131-146.

[7] Davidov, M., \& Grusec, J. E. (2006). Untangling the links of parental responsiveness to distress and warmth to child outcomes. Child Development, 77(1), 44-58.

[8] Eagly, A.H. and Karau, S. (1991). Gender and emergence of leaders: a meta-analysis. Psychological Bulletin, 60(5), 685-710.

[9] Farrell, L. (1998). You've got to be kidding: humour as a fundamental management tool. ARMA Records Management Quarterly, 32(3), 3-8.

[10] Heller, W., Nitschke, J. B., \& Miller, G. A. (1997). Lateralization in emotion and emotional disorders. Current Directions in Psychological Science, 7(1), 26-32.

[11] Hemsath, D. (1997). Are we having fun yet?. The Journal for Quality and Participation, 20(5), 32-53.

[12] Kilman, R.H. and Thomas, K.W. (1977). Developing a forced choice measure of conflict-handling behaviour: the 'MODE' instrument. Education and Psychological Measurement, 3(2), 309-25.

[13] Leary, M. R., Twenge, J. M., \& Quinlivan, E. (2006). Interpersonal rejection as a determinant of anger and aggression. Personality and Social Psychology Review, 10(2), 111-132.

[14] LeVine, R. A., Miller, P. M., \& West, M. M. E. (1988). Parental behaviour in diverse societies. San Francisco, CA: Jossey-Bass.

[15] Maccoby, E. E., \& Martin, J. A. (1983). Socialization in the context of the family: Parent-child interaction. New York: Wiley.

[16] Putnick, D. L., Bornstein, M. H., Lansford, J. E., Malone, P. S., Pastorelli, C., Skinner, A. T. \& Alampay, L. P. (2015). Perceived mother and father acceptance-rejection predict four unique aspects of child adjustment across nine countries. Journal of Child Psychology and Psychiatry, 56(8), 923-932.
[17] Rasmusson, E. (1999). A funny thing happened on the way to work Sales and Marketing Management, 151(3), 97-8.

[18] Rohner, R. P. (1984). Toward a conception of culture for crosscultural psychology. Journal of Cross-Cultural Psychology, 15(2), 111-138.

[19] Rohner, R. P. (2004). The parental acceptance-rejection syndrome: universal correlates of perceived rejection. American psychologist, $59(8), 830$.

[20] Rohner, R. P. (2004). The parental "acceptance-rejection syndrome": universal correlates of perceived rejection. American psychologist, 59(8), 830.

[21] Rubin, J., Provenzano, F., \& Luria, Z. (1974). The eye of the beholder: Parents' views on sex of newborns. American Journal of Orthopsychiatry, 44(1), 512-519.

[22] Shih, H. A., \& Susanto, E. (2010). Conflict management styles, emotional intelligence, and job performance in public organizations. International Journal of Conflict Management, 21(2), 147-168.

[23] Shulman, B. H., \& Mosak, H. H. (1977). Birth order and ordinal position: Two Adlerian views. The Journal of Individual Psychology, $33(1), 114-121$

[24] Vokic, N. P., \& Sontor, S. (2009). Conflict management styles in Croatian enterprises-The relationship between individual characteristics and conflict handling styles. Faculty of Economics and Business-Zagreb, 41(2), 322-338

[25] Whiting, B., \& Edwards, C. P. (1988). A cross-cultural analysis of sex differences in the behaviour of children aged 3 through 11 . Childhood Socialization 23(1), 281-297).

[26] Williams, K. D., \& Zadro, L. (2001). Ostracism: On being ignored, excluded, and rejected. Interpersonal Rejection, 7(1), 21-53. 